\title{
CULTIVATING LOCAL WISDOM IN CHARACTER EDUCATION: LESSONS FROM FAMILY EDUCATION VALUES OF INDONESIAN TRADITIONAL CEREMONY
}

\author{
TESTIANI MAKMUR ${ }^{1 *}$, WENNY DASTINA ${ }^{2}$ \\ ${ }^{1}$ Universitas Islam Negeri Sunan Kalijaga Yogyakarta \\ ${ }^{2}$ Universitas Islam Negeri Sulthan Thaha Saifuddin Jambi
}

\section{Abstract}

The tradition of establishing a house in Tanjung Pauh, Kerinci contains noble educational values such as deliberation, mutual cooperation, togetherness, knowing and helping each other, monotheism, recalling kindness, and courtesy. Those values are aligned with the concept of character education proposed by Thomas Lickona. The values can be implemented into family education especially in rural communities of Tanjung Pauh, Kerinci. The character values in harvesting rice carried out by the community teach civilized attitude towards plants and sharing with others. Besides, the community also has principles of respect, attention, respect, and compliance with customs regulations. The ceremony is performed based on custom and religious teachings with the intention to reject any disasters experienced by human beings, plants, and animals. Besides, the ceremony performed contains meanings of gratitude to God Almighty in order to reduce the punishment of the grave space, especially for parents who died and owned rice fields. For those who are still alive, these activities are carried out with the hope that everything done runs well, gains healthy bodies and longevity.

\footnotetext{
* Corresponding author: Testiani Makmur, Jl. Laksda Adisucipto, Sleman, Yogyakarta, Indonesia, 55281. Email: sholiatalhanin@yahoo.co.id 
Tradisi membangun rumah di desa Tanjung Pauh, Kerinci mengandung nilai-nilai lubur pendidikan bagi generasi selan-jutnya seperti musyawarah, gotong royong, kebersamaan, saling mengenal, tolong menolong, taubid, mengenang kebaikan, dan adab. Nilai-nilai tersebut selaras dengan konsep pendidikan karakter yang diutarakan oleh Thomas Lickona. Nilai-nilai tersebut dapat implementasikan kedalam pendidikan keluarga masyarakat Kerinci khususnya di desa Tanjung Pauh, Kerinci. Nilai karakter dari kegiatan menuai padi yang dilakukan oleh masyarakat yaitu adab bersikap terhadap tumbuh-tumbuhan dan berbagi dengan yang lain. Selain itu, masyarakat tersebut juga memiliki prinsip-prinsip penghar-gaan, perhatian, penghormatan dan kepatuhan pada peraturan adat. Masyarakat juga menyelenggarakan upacara tolak bala yang dilakukan secara adat dan ajaran agama yang memiliki makna untuk menolak segala jenis bencana baik yang dialami manusia, tumbuhan maupun binatang. Disamping itu, upacara tolak bala yang dilakukan juga mengandung makna rasa syukur atau ucapan terima kasib kepada Tuhan yang maha kuasa agar diberikan kelapangan azab kubur khususnya kepada orang tua yang sudah meninggal dunia dan mempu-nyai sawah. Adapun bagi mereka yang masib hidup, kegiatan tersebut dilakukan dengan harapan mendapatkan kelancaran atas apa yang dikerjakan, kesehatan serta panjang umur.

Keywords: character education; cupak gantang; family education; local wisdom; traditional ceremony.

\section{Introduction}

Education should construct intelligence, conduct transfers of knowledge, and build character education and behavior. Former Indonesian President, Susilo Bambang Yudhoyono, said that Indonesia's education should transfer not only science and technology but also establish the values and character of the nation (Mulyadi 2011). These two elements are crucial in character education. In the education context, it is necessary that the culture must participate therein. The culture cannot stand 
without education, and it will always be in the scope of culture (Hasanah 2012). The relationship between education and culture is inseparable and interconnected (Tilaar 2004). Therefore, the blend of education and culture leads to character education. It should be applied in a variety of social order, formal and nonformal education. One of the non-formal educational settings is a family environment. Koesoema suggests that an effective and intact character education includes three basic designs. One of them is a community-based character education design. In this design, components outside educational institutions, such as a family, have a moral responsibility to integrate the formation of character in the context of life. This design is reinforced by Phillips' statement saying that character education should involve all parties; home and family; school; and wider school environment or society (2010).

The implementation of character education in a family is necessary because the family is a core of society which becomes the primary school for children. Consequently, it provides a learning space which is very influential on the formation of character. In the globalization era, character education is required because the condition of people behavior is increasingly distant from the noble values that exist. They seem to have lost character, in both the social order and the family. In this regard, character education is one solution that prevents moral deterioration in a nation. Ironically, the family often ignores and submits character education to schools (Pribadi 2012). The families should introduce values, cultural, moral, and religious skills to children. The ability of the family to run character education becomes the pillar of it (Warsidi 2017). One of the ways to realize character education is through culture or local wisdom. Local knowledge as a part of the cultural construction refers to everything owned by local communities in particular areas that characterize the 
originality and uniqueness without any influence or mixture of elements from other areas.

The values applied by particular groups of people reflects the sustainability of local wisdom. Community groups hold hereditary values firmly. In Kerinci community, the noble values can be found in a traditional ceremony Cupak Gantang Kerja Kerapat maintained by the entire regions including Tanjung Pauh Kerinci village. The traditional ceremony of Cupak Gantang Kerja Kerapat has a sense that a traditional ceremony related to livelihood and social life of the community must be done through working together such as building a new house, harvesting rice, ceremonies rejecting reinforcements, and requesting for rain. The tradition has the meaning and function of goodness and nobility. In the transformation process of delivering moral value messages, shared values strengthen the relationship and emotion for the establishment of a forum for communication between young and old; form a concern for others; embody the attitude of helping each other; and familiarize cooperation as a means of fostering life norms. Everything is a feature of the character and identity.

The problem is on how to implement and take the meaning of local wisdom as the basis of character education in Kerinci community mainly in the ceremony of Cupak Gantang Kerja Kerapat. Local wisdom will be eternal when it is implemented in real everyday life and become a major cornerstone in the family, so it is not just a mere tradition. Should the values of Kerinci local wisdom not be implemented in family education, they would be lost over time. Consequently, the norms and values of Western culture are the ones that will be implemented instead of the values of local knowledge. A wealth of local wisdom in Indonesia has an important role in shaping the character education (Fajarini 2014). The results of Alfian Magdalia research indicates that 
many young people are not familiar with and runs local wisdom traditions. It is caused by a family education that begins to leave the local traditions and does not apply identity strengthening the family as an element of local knowledge (2013). Kartadinata reinforces this argument in Alwasilah (2009) which states that many people who are dazzled by the Western education system are blind to the benefits of the local culture long buried in the earth of Indonesia. Likewise, Ruyadi explains that the source of character values is derived from the cultural environment of the school, families, and communities (Ruyadi 2010). Therefore, the local identity has noble values that need to be cultivated and invested in family education.

The traditional ceremony of Cupak Gantang Kerja Kerapat is considered essential to be studied since this study intends to explore, assess, locate and reconstruct the noble values contained in Tanjung Pauh community, Kerinci so that the tradition can be maintained. In addition, Maryani suggests the importance to explore, discover, develop and transmit moral values derived from the local cultural superiority because wisdom is a necessity (Maryani and Yani 2016). This was confirmed by Mohammad suggesting that character education based on local wisdom includes two actions that must be done by the people. The first, they should keep the preservation of traditional values held so that the identity and cultural practices are not exploited by foreign culture. Secondly, they should raise public awareness to explore and understand the values contained in customs (Priyatna 2017). The local values in the development of character education can later be introduced and re-applied specifically in shaping the almost forgotten character education of Kerinci community. The role of the family in forming character becomes a crucial key because it is the first school for the family. Sumaryadi supports by stating that family is the first strategic and conducive 
environment to values cultivation (Sumaryadi 2012). Therefore, the local wisdom values should be embedded and explored in family education continuously in order to be used as the basis of family education implementation. This is in line with Asrianti's argument stating that Indonesian people should return to their identity through reinterpretation and reconstruction of noble cultural values (Asriati 2013). For that purpose, the values are inculcated within the frame of character education

Character education relates to cultures, ethics, and morals. The Indonesian Dictionary defines characters as psychological traits, morality, or character that distinguishes someone from other people. Popular Scientific Dictionary defines character as disposition or habit. The definitions are reinforced by Suyanto's description that mentions nine pillars of character derived from universal noble values, namely God's love character and all of His creations; independence and responsibility; honesty, trustworthiness and diplomatic; respect and courtesy;being generous; being helpful and mutual cooperation;confidence and hard work; leadership and justice; kind and humble; tolerance, peace and unity (Suyanto 2010). These values are in line with Lickona's concept that character contains three essential elements, namely knowing the good, loving the good, and doing the good (Lickona 2009). Kirschenbaum furthermore says that character education has a close relationship with components of knowledge of moral tradition, moral reasoning, compassion and altruism, and moral inclination (Kirschenbaum 1995).

Character education is a system of cultivating character values which includes components of knowledge, awareness or willingness, and actions. It is done by someone to carry out life values toward God, oneself, human beings, nature and environment, and nationality to become a noble human one. Character education deals with various aspects of moral 
education, civic education and character development (Latif 2009). However, character education should not leave and apart from the local wisdom that exist in a society.

Local wisdom refers to traditional and unique knowledge developed by people at specific conditions in some geographical regions (Larasati 2012). The characteristics of local wisdom are based on experience; tested after centuries; adapted to current culture; combined in the daily practices of people and institutions; commonly carried out by individuals or society as a whole; characterized dynamic and continuously changing, and related highly to the belief system (Kirschenbaum 1995). All forms of local wisdom are lived out, practiced, taught and passed down from generation to generation to shape human behavior pattern toward other human beings, nature, and supernatural things (Keraf 2010). A number of experts classify local wisdom into five categories namely wisdom in the form of philosophy; wisdom in the form of social life attitudes, and advice revealed in the form of proverbs, parables, poetry or folklore; wisdom in the form of traditional ceremonies; wisdom in the form of principles, norms, and rules that are tangible into social system; wisdom in the form of habits and daily behavior in social interaction (Rasyidin, Siregar, and Batubara 2009). Therefore, it imperative to investigate how those forms of local wisdom were practiced and implemented by a community. One of the communities that practiced them was Kerinci community.

Kerinci has had its customs for centuries ago. Since the animism and dynamism era, Kerinci tribe has had the order and outlook of life that become a guideline. When Islam arrived, the influence of animism and dynamism slowly came to decrease, in which they turned into beliefs in the religion of heaven. In general, the native people of Jambi including Kerinci traditional tribe recognize and organize certain traditional ceremonies to date, both ceremonies related to beliefs and those related to 
the religion of Heavens (Islam). From the rituals of traditional ceremonies, it is clearly illustrated how the relationship between humans and supernatural powers is beyond the human power that influences their lives. Therefore, the people of Alam Kerinci have many ceremonies and traditional arts in each indigenous region or country depending on the ico used in each neghoi (village).

This study is aimed at revealing some problems as follows: (1) How can local wisdom-based character education in Kerinci family education be viewed from the tradition of establishing of a new house? (2) How can local wisdom-based character education in the family education of Kerinci community be seen from the tradition of mutual harvesting? (3) How can local wisdom-based character education in the family education of Kerinci community be viewed from the tradition of rejecting reinforcement and disaster, and requesting rain ceremonies?

The setting of this study was Tanjung Pauh village, Kerinci Regency. It was conducted from May to July 2018. The types of data collected were primary data and secondary data that were qualitative. To uncover problems and get accurate data, several methods of data collection were used such as semi-structured interviews and observations. In determining informants, researchers used a purposive sampling technique. In this case, the researcher only discloses the criteria as a requirement to be sampled. With this Purposive Sampling technique, informants were chosen who were considered to understand Kerinci's local wisdom-based education. The informant consisted of 6 people who were selected with special conditions, namely the clerics and the old figures. After obtaining data from the field through observation, interviews and document studies, data analysis or data processing was carried out through several stages including data reduction, data presentation, triangulation, and concluding. 
Local Wisdom-Based Character Education in the Family Education of Kerinci Community in the Tradition of Establishing a New House

The tradition of mutual cooperation to establish houses in Tanjung Pauh began since the existence of life in that village because there were still few people at that time. One village had only a few families, so other family members should be called and invited to establish houses because they could not do it themselves. Then the negotiations were carried out to carry out mutual cooperation (kinerjaosamo) to establish houses (umab). The mutual cooperation tradition began to disappear in Tanjung Pauh because of the increasing population composition. The loss of the tradition is illustrated in figure 1.

Figure 1

The beginning of the loss of mutual cooperation (gotong royong) tradition in establishing houses

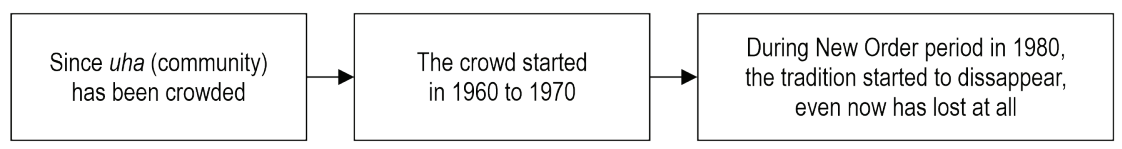

The process of establishing a house in the age of ancestors in Tanjung Pauh was illustrated in the figure 2.

Figure 2

Preparation for establishing a house

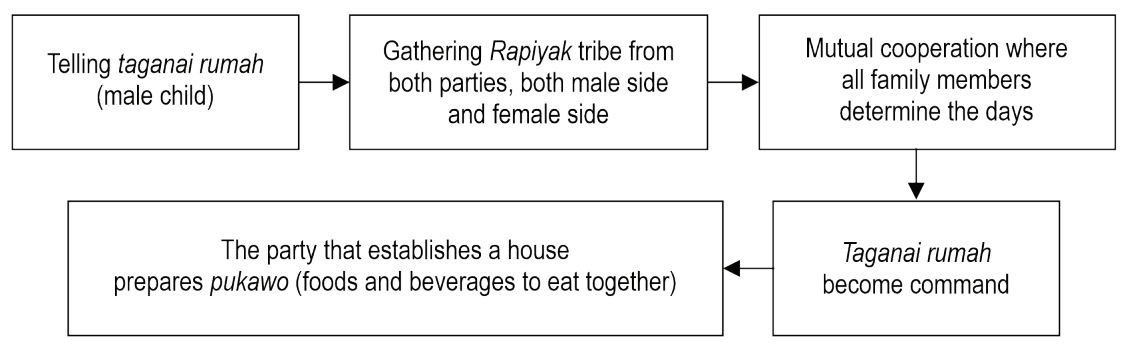

Mutual cooperation in establishing houses is not related to tradition, but it is related to taganai (male child). Ajun 
arah (asking/giving directions) has a relation with depati ninik mamak ${ }^{2}$. The process of establishing houses in Tanjung Pauh must go through a series of stages which start from panggan or inviting depati ninik mamak and asking for ajun arah to ninik mamak. This stage means that the party, who builds the slaughter house, occupies or respects ninik mamak. The next stage is process of asking for direction is carried out by giving uang arah. After ajun arah is carried out, there is no more extended responsibility of ninik mamak, and the family wholly owns the responsibility. Ninik mamak's direction to protect border is aimed that there is no land dispute in Tanjung Pauh and always obey the rules. If the land that will be used to establish a house has not been completed or is still in dispute, ninik mamak will not give direction. Meanwhile, the types of assistance brought by public and Due Rupiyak tribe when building houses are shown in figure 3.

Figure 3

Types of assistance when establishing houses
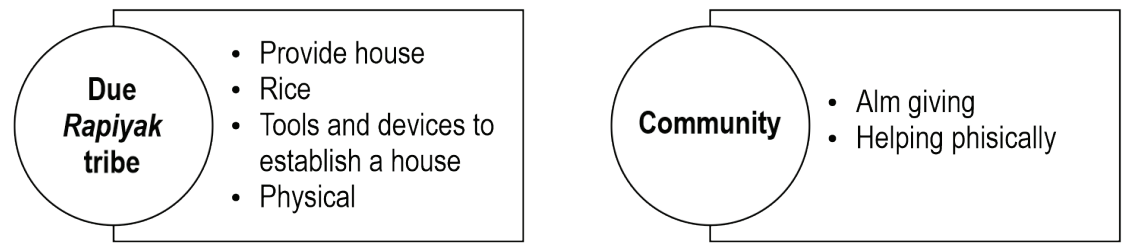

The tradition of mutual cooperation to establish houses in Tanjung Pauh has mok nyo salah purpose i.e., to be agreed, simultaneous, and merged. Thus, the tradition of building a house contains values to educate the next generation. These values are useful not only to strengthen unity and kinship but also to increase harmony in the life of society in general. Also, the tradition also serves as a vehicle for establishing a sense of

${ }^{2}$ Depati ninik mamak is the chieftain, the highest symbol in the Kerinci society which is in charge of giving direction or advice to the community. 
togetherness; a forum for communication between the older and the younger generation; and a means of fostering traditional values that are timeless. In general, the tradition also contains values such as (1) the principle of deliberation, by prioritizing deliberation for consensus, (2) mutual cooperation to unite and blend into one feeling, (3) togetherness, with the principle of Brotherhood between those who establish a new house with Rapiyak tribe, the community, and depati ninik mamak, (4) the principle of mutual understanding by recognizing the maternal lineage of the parents to the ancestors so they can find out who their ancestors, the grandparents, and the siblings of parents are, (5) principles of responsibility, where the responsibility of the male child or teganai rumah become a mutual assistance command while establishing the house. Depati ninik mamak has a responsibility in giving directions so that land boundaries do not become dispute in the future. At the same, the responsibility ensures that there is no other people land is used. Such principle teaches people not to take rights of others and maintain togetherness, (6) the principle of help is based on selfless sincerity without asking for compensation, and (7) the principle of not to take the rights of others.

Those principles are in line with the concept of character education proposed by Thomas Lickona which consists of good behavior, honesty, responsibility, respect for the rights of others, hard work, etc (Lickona 2009). The concepts are reinforced by Noide's argument stating that cultural values primarily consist of mutual cooperation, friendship, and solidarity (Niode 2007). However, the present condition shows that there is no invitation to do mutual cooperation to build a house. In contrast to the past, depati ninik mamak encouraged residents to work together because the number of people was still few and the encouragement was limited to words. The difference is described in figure 4. 
Figure 4

The difference between past and present mutual cooperation in establishing houses
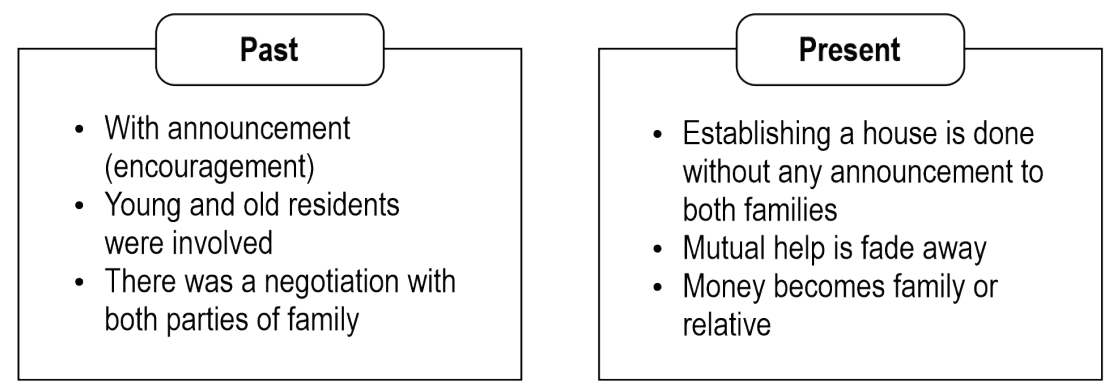

Some parties take part in mutual cooperation in establishing houses in Tanjung Pauh, Kerinci. Those parties are Rapiyak tribe, taganai (male child), depati ninik mamak, and the community. The parties involved have different roles as explained in table 1.

\section{Table 1}

The roles of those are involved in mutual cooperation in establishing houses

\begin{tabular}{ll}
\hline Rapiyak tribe & $\begin{array}{l}\text { Helping to invite people, cook, and provide material and } \\
\text { physical. }\end{array}$ \\
\hline Taganai (male child) & Becoming heap to know which one is light or weight. \\
\hline Depati ninik mamak & Giving ajun arah \\
\hline Community & Helping physically and take sekauh. \\
\hline
\end{tabular}

The people who take part in mutual cooperation in establishing houses use various tools such as axes, saws, chisels, hoes, and some other tools. The tool traditionally has meaning, for example, which long chains should be cut; which chisels that should be punched; and which axes that have not been connected should be joined. In other words, all of these activities have meaning concerning the human relationship. Those who are distant should be called, and those who are closed should be collected so that all can be united. Thus, mutual cooperation to establish a house has the function to unite all relatives of both 
parties and the community. Whereas when they establish a house they sprinkle the sarigin ${ }^{3}$ on the pillar of the house while reciting certain sentences. Sarigin and the expression are as illustrated in figure 5 .

Figure 5

The content of sarigin and sentences expressed

\begin{tabular}{|l|} 
The content of sarigin \\
- Kundo \\
- Sa Tawa \\
- Sa Dingin \\
- Sa Tajing \\
- Ke Kaha Kumpe Alang
\end{tabular}

The sentences expressed
Kamai neh ndak nikiek umah, inin ntah adu tanah setempak adu
isie, kito idiek Nampak laieh. Ngilak kayo kamai neh ndauk gawi
enta ineh, kami ndauk ngerju alat umah, ntah adu kayo inik kamai
lepeh saragin ngilak kayo lahai kayo dari inik, ilak di tujiek
matahari jetauuh, inauk tempek kayo, jik kayo uduk inik. mauek
lah kayo ngabu-ngabu kamai. Lu lah kamai idak Nampak leh,
kayu batubuh alauh.
We want to build a house here but each land has a guard or
occupant, while we do not see who is waiting. Avoiding Kayo, we
want to work here we work on home appliances, whether there is
Kayo or not here we let saragin go please do Kayo avoid, go
Kayo from here, go to the sunset, there Kayo place is. If Kayo sits
here, don't Kayo disturb us. Understandably, we don't seem to
see Kayo who is invisible.

The reason for expressing the sentence is because they believe that every land has its occupants and each tree has its contents. This is a form of belief in other beings. It is in line with the Islamic concept of believing in qada and qadar. Before sarigin is released in the house area, prayers and șalawat are read as rejecting reinforcements to be safe. Prayers are also given to lighten the torment of the grave of the person who owned the land of both parties. This is with the aim to remember the services of parents who had cut the wood by hand. All of this is done because the land used by the community to build a house in Tanjung Pauh in Kerinci was formerly a jungle. The differences and similarities in mutual cooperation tradition in establishing houses in Tanjung Pauh, Kerinci are as illustrated in table 2.

${ }^{3}$ A traditional herb that is used in the indigenous events of Kerinci, in addition to traditional medicine to cool the fever and treat the diseases. 
TESTIANI MAKMUR AND WENNY DASTINA

\section{Table 2}

Differences and similarities of the mutual cooperation tradition in establishing houses

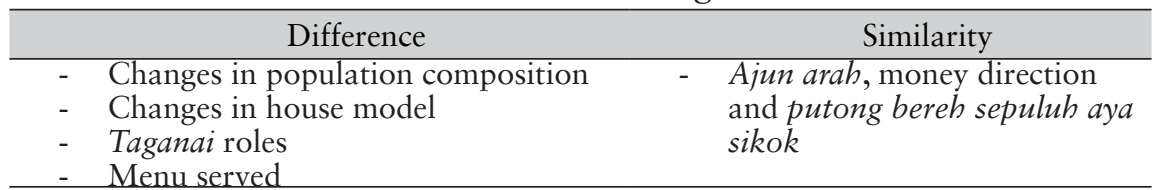

From the activities of establishing new houses, there several values of character education that can be conclude, for example (1) unifying the fraternity of all relatives of mother and father sides, either near or far; (2) Tawhid principle where each work is always preceded by prayer and salawat so that what is done is safe; (3) The principle of recognizing or remembering goodness through gratitude, considering the services of previous parents, glorifying ancestral spirits because they have cut down wood and left land inheritance for posterity; and (4) Adab (courtesy) principle namely mutual respect and ethics among creatures of God, either those can be seen by the eyes or those cannot be seen by the eyes. Supporting the last value, Buya Hamka states that the inability of our eyes in seeing the other creatures does not mean that they do not exist. Instead, it is only caused by our eyes that cannot see them (Hamka 2015).

Those noble values should be implemented into family education in Kerinci community especially in Tanjung Pauh because they contain principles of monotheism, remembering goodness, $a d a b$, and brotherhood. These values are in line with the 2010 Ministry of National Education Curriculum which contains 18 values of character education such as religious, caring, respecting and many others. Therefore, character education in Indonesian context refers to noble values that originate from culture (Gunawan 2012).

There are several factors why mutual cooperation tradition in establishing new houses is not maintained. The factors are: (1) 
people bustle, (2) diminished social sense, (3) diminished sense of brotherhood, (4) the society point of view, (5) the view that the old tradition is considered to be left behind , (7) individual attitudes, (8) selfish attitudes, and (9) the abandonment of traditional lessons. The step to restore the tradition of mutual cooperation in establishing new houses is to unite tradition with sharia.

Figure 6

Restoring the tradition of mutual cooperation
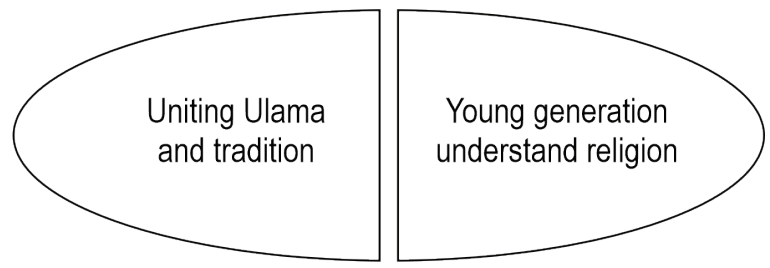

Uniting ulama and tradition are highly necessary because both parties cannot be separated in returning to old traditions. Meanwhile, religious and customary leaders seem to blame each other so far. When ulama and tradition are not united; the younger generation also does not understand religion; so returning to the old tradition will be difficult. On the other hand, cultural values and traditions must be maintained and inherited through three educational institutions, namely community, family, and traditional ceremonies (As'ari and Hendriawan 2016). The same thing is also stated by Sumaryadi arguing that the civilization process is found in three pillars, namely the pillars of family, school, and society (As'ari and Hendriawan 2016). Even traditional ceremonies are good social media and intermediary factors that become the basis of activities and social interactions in a community (Santoso 1984).

Character Education-Based on Local Wisdom in Family Education in Kerinci Community Viewed from the Tradition of Harvesting Rice 
The tradition of reaping rice in Tanjung Pauh, Kerinci has become a tradition inherited for centuries. In the past, the tradition was called manuee, in which its early history was carried out to unite young people because there was an element of joy through mutual help. Gadieh (girl) sometimes helps bujang (boy), and vice versa, bujang sometimes helps gadieh. When carrying out mutual cooperation in manuee, both gadieh and bujang do ngaro or 'unrequited rhymes' that make them happy and enthusiastic to work (begawe).

When menuee is in the place of a teacher, a traditional healer, ninik mamak and pegawi, then an advice to the community to participate in mutual cooperation to harvest rice is announced. Menuee rice activities in general public involve only young people. Advice and involvement in mutual cooperation to reap rice are conveyed by sounding the sign (sana). More details description is described in figure 7.

\section{Figure 7}

Advice and involvement to carry out mutual cooperation in menuee rice

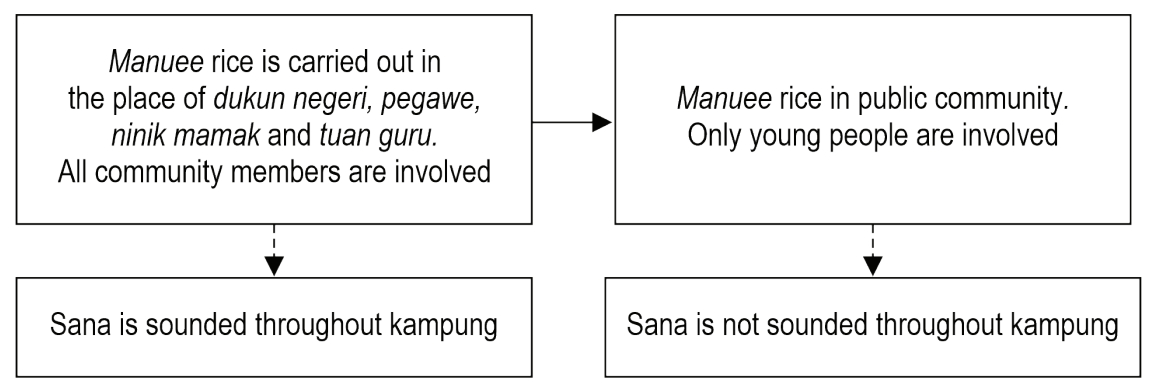

The advice was delivered by sounding uleee baliee around the village. When sana is sounded around the village, the sign shows that there is important news from their tradition. If the community does not heed the customary appeals such as by being absent in mutual cooperation, they will be fined on a shared basis which is adjusted to traditional decisions. Customary fines are usually in the form of money, namely one rupiah, twenty- 
five rupiahs or the equivalent of wages of helping menueei in a day. Thus the values contained in special advice for mutual cooperation are the principles of respect, attention, respect, and compliance with the customary rules and leaders.

The reasons why the tradition of mutual cooperation to reap rice is not maintained are due to lack of social sense between the family and the community and selfishness or individualism so that the present generation does not understand tradition and sharia. This is in line with Koentjaraningrat's concept that before money becomes an economical means, agricultural activities are carried out in mutual cooperation by the community. After the money is used, human labor that mutually works together is replaced by money and a rent system (Koentjaraningrat 2009). The step to restore the tradition is by uniting tradition and sharia. This step must be carried out because both tradition and religion are aimed to bring individual community members into social beings. As long as both parties do not unite, they will still blame each other. If not done, it will be difficult to restore the noble tradition that contains sacred and aesthetic values between humans, nature and other creatures. However, maintaining tradition or local wisdom as a medium for strengthening the identity of regions and filtering out values originating from outside are very crucial. As Ayatrohaedi states that the nature of local wisdom is the ability to control foreign cultures (Ayatrohaedi 1986).

\section{Character Education-Based on Local Wisdom in Family Edu- cation of the Kerinci Community Viewed from the Tradition of Rejecting Reinforcement Ceremony}

The tradition of rejecting reinforcements in Tanjung Pauh, Kerinci is held every year in the month of Safar. It is carried out regularly when the rice menuee has finished. The origin of the tradition cannot be explained in a definite and detailed manner because this tradition has been done from generation to 
generation. The ceremony of rejecting reinforcement in Tanjung Pauh, Kerinci has the purpose of refusing to reinforcement and disposing of bad luck. The purpose could be described in figure 8. The community organizes the rejection of reinforcement ceremony based on tradition and sharia manner as described in figure 9.

Figure 8

The purposes of rejecting reinforcement ceremony

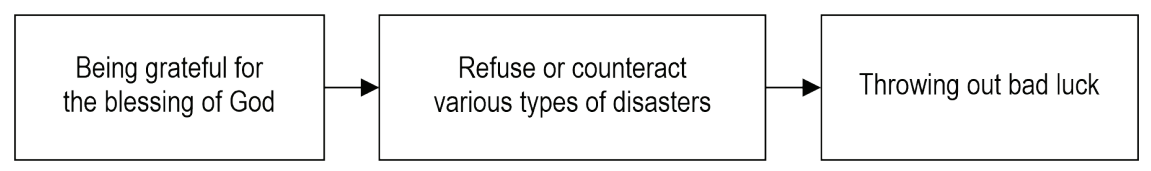

Kerapat tradition determines the ceremony of rejecting reinforcement and done at the end of Friday night. The ceremony involved depati ninik mamak, mosque administrators, religious scholars, community and community figures. Hajat prayer performed at depati ninik mamak house have conditions that must be fulfilled, namely mutung bareh sepuluh aya si ikok. On the other hand, if the prayer is held at the mosque, it is necessary to throw away the disease to tayeik in the month of Safar and do thanksgiving at the community's house in which there are no conditions for the ceremony. The ceremony of rejecting reinforcements is held not only at the house of depati ninik mamak or in mosques, but also at community's houses. The ceremony in community houses is limited to give alms telo and invite only certain people. Alms telo is limited only to pray to be safe in everything. However, the ceremony of rejecting reinforcement and alms telo are not held again nowadays. The tradition is not maintained because it is considered contrary to religion and lack of public knowledge about adat or customs. Such a view indirectly punishes local wisdom with the legal formalistic paradigm. Legal Formalistic paradigm is a black-andwhite perspective that prefers to punish without considering the philosophy and historical background contained in (Rahimin Affandi Abd. Rahim et al. 2012). 
CULTIVATING LOCAL WISDOM IN CHARACTER ...

Figure 9

The ceremony of rejecting reinforcement based on custom (adat)

and sharia
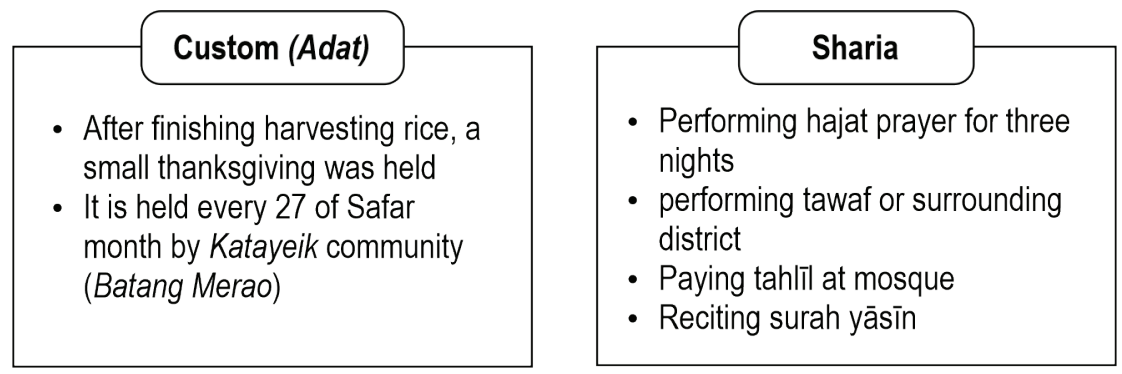

Based on these reasons, it will be difficult to restore the tradition of rejecting reinforcements by custom. It is necessary to unite between custom and ulama to sit together and discuss in order to find solutions to revive the noble traditions. By reviving the old tradition, the effort to maintain cultural existence has been carried out by introducing the philosophy and historical background contained in it and filtering the entry of foreign cultures. Sumaryadi (2012) argues that the main elements that must be preserved are natural, socio-cultural and economic. The main objectives of ensuring the sustainability and existence of local wisdom are that the previous, now, and future generations have equal rights and opportunities to enjoy the existing local wisdom. Currently, the rejecting reinforcement ceremony which is still be carried out is Hajat prayer. Through that prayer, people can convey various desires, including rejecting reinforcement. In addition, rejecting reinforcement is also carried out on Friday by reading qunūt prayer without any tawaf or surrounding the village.

\section{Character Education-based on Local Wisdom in Family Educa- tion of Kerinci Community Viewed from the Traditional Cere- mony of Requesting Rain}

The ceremony of requesting rain is a ceremony to ask the rain to God which is done during the long dry season. In Tanjung 
Pauh, Kerinci the ceremony to request rain is carried out in two ways, namely by tradition and religion as illustrated in figure 10 .

Figure 10

Ceremony for requesting rain by tradition and religion

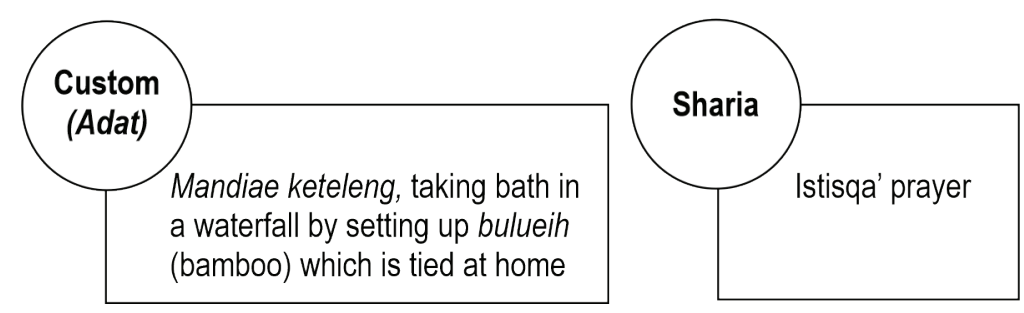

The summary of the traditional ceremony procession can be explained in figure 11.

\section{Figure 11}

Process of requesting rain ceremony by custom

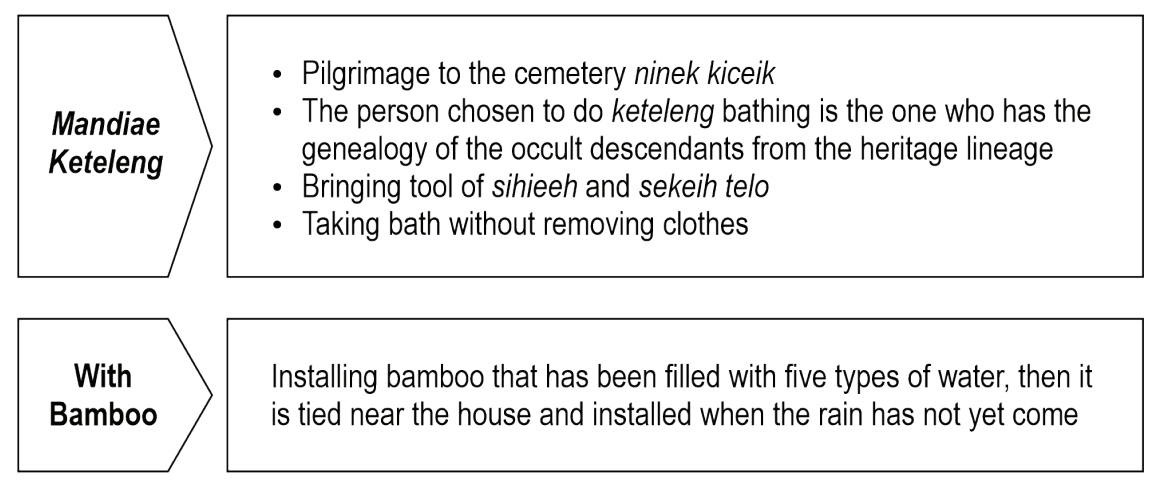

This ceremony is not maintained traditionally but is still maintained in sharia through istisqa' prayer. On the other hand, the ceremony of requesting rain by sharia is done in the field by bringing all living things such as chickens and others. The istisqa' prayer is announced through the mosque, so the entire community participates. The conditions of istisqa' prayer are adjusted to religion. In line with the observations of researchers in the field, the tradition is not performed anymore because the ritual of requesting rain by custom is considered contrary to religion; and the different religion understanding, so it is 
considered not in accordance with religious teachings. In this case, local cultural values should be seen as a social inheritance and community dignity entity, not vice versa as something that is contrary to religion or not in accordance with the era.

Geertz believes that local wisdom is an entity that significantly determines human dignity and values in the community. Therefore, when traditional values that exist in the community are lost, the community will lose their identity and their sense of pride and ownership (Ernawi 2010). On the other hand, identity is a cultural character that functions as a character builder (Lubis 2008). Thus, the way to restore the ceremony for requesting rain by custom is by uniting tradition and religion, and not assuming that the tradition is misguided because it contains noble values. Custom and ulama should strengthen the noble values of local wisdom because they are the spearhead in maintaining tradition. This opinion is not much different from Christeward's argument on cultural preservation which demands the institution's active roles and village stakeholders to cooperate with the community in maintaining cultural values and local wisdom (Alus 2014). Therefore, the factor in reviving the noble tradition needs to involve custom, ulama and the community. Meanwhile, the noble values contained in the ceremony of requesting rain are a mutual need and religious principles.

So, it is crucial to make the noble values found in the mutual cooperation ceremony to establish a house, reap rice, reject reinforcements and request rain as learning sources in family education. By implementing noble values such as mutual cooperation, monotheism, appreciation, deliberation, responsibility, brotherhood, and togetherness, motivation, happiness, courtesy toward plants and other beings, obedience to regulation and leaders, remembering kindness, attention, and sharing. All of those values will have a good impact on all 
components of the family. Such attitudes are needed in family education because, in the current globalization era, people are increasingly distant from noble values where they measure brotherhood with money, mutual help is wan and replaced by individualism, not knowing bloodlines, even religious education is put aside.

\section{Conclusion}

The beginning of mutual cooperation tradition in establishing houses in Tanjung Pauh occurred since the existence of life. Therefore, negotiations were carried out customarily to carry out mutual cooperation in establishing umab (houses). The increasing population composition influenced the loss of tradition. Mutual cooperation in building a house was considered not related to custom, but it was related to taganai (male child). Activities related to custom are the activities of ajun arah (giving/requesting directions). The purpose of mutual cooperation tradition was to establish houses in Tanjung Pauh village, namely, mok nyo salah (agreed, simultaneous, and unite). Meanwhile, the tradition of establishing new houses in Tanjung Pauh, Kerinci contained educational values intended for the next generation including (1) the principle of deliberation, by prioritizing deliberation for consensus, (2) mutual cooperation to blend into one flavor, (3) togetherness and brotherhood principles, (4) mutual acquaintance principle, (5) responsibility principle, namely the responsibility of the male child and depati ninik mamak, (6) helping principle which was based on selfless sincerity and asking for compensation. Activities carried out during the establishment of new houses also had meanings in character education, uniting the spirit of brotherhood of all relatives of both parties, both mother and father. The monotheism principle was cultivated in the tradition because every work was always preceded by prayer and șalawat so that what was done is 
safe. Besides, the tradition also inculcated principles of knowing goodness, thanking with constant remembrance of parents' services, glorifying ancestral spirits because they have been struggling to cut wood, leaving the land inheritance to posterity; and courtesy for mutual respect and ethics toward creatures of God.

The tradition of reaping rice in Tanjung Pauh Hilir, Kerinci, had become a tradition that has been carried out from generation to generation. Manuee's early history was to unite young people in joy. The process of harvesting rice contains the values of courtesy toward plants and sharing. The values contained in the special advice for mutual cooperation in reaping rice are principles of respect, attention, respect, and community's compliance with traditional regulations. The factor that caused tradition of mutual cooperation to reap rice had not been maintained was due to lack of social sense between family and society, selfishness and lack of understanding custom and sharia by the current generation. The way to restore this tradition is the union between custom and sharia. As long as custom and sharia were not united, efforts to restore the noble traditions that were full of sacred and aesthetic values between humans, nature and other creatures would be complicated to be realized. The union between custom and sharia was a way to save, expand and strengthen traditions so that they could function as religious and social.

The beginning of rejecting reinforcement tradition could not be explained clearly and in detail. This tradition had been carried out since the ancestor time. Rejecting reinforcement ceremony in Tanjung Pauh, Kerinci had the purpose to thank for Allah's blessings, reject various types of disasters, and throw off bad luck. The implementation of rejecting reinforcement ceremony was carried out by custom and sharia. It was carried out (1) 
whenever harvesting rice was finished, (2) at the end of Safar month (around Safar 27), and (3) every Monday, Tuesday, and Wednesday night. The ceremony involved depati ninik mamak, mosque officials, religious scholars, community figures, and community.

The ceremony of requesting rain was a ceremony made by begging God during the long dry season. The ceremony was held in two ways, namely custom and sharia (religion). The former was made by mandiae keteleng (bathing in a waterfall) and installing bulueih (bamboo) tied at home. The latter was made by istisqa' prayer which was announced through the mosque and all people participated. Traditional ceremony by custom was no longer maintained but the one by sharia, istisqa' prayer, is still being maintained. The ceremony by sharia even is not performed for ten years because the long dry season does not occur. The ceremony by custom is not performed anymore because it is considered a heretical, different understanding of religious teaching, and assumptions that are not in accordance with the religious beliefs. In general, the values contained in this ceremony are the mutual need and religious principles.

\section{Bibliography}

Alus, Christeward. 2014. "Peran Lembaga Adat dalam Pelestarian Kearifan Lokal Suku Sahu di Desa Balisoan Kecamatan Sahu Kabupaten Halmahera Barat.” Acta Diurna 3 (4): $1-16$.

Alwasilah, A. Chaedar, K. Suryadi, and Tri Karyono. 2009. Etnopedagogi: Landasan Praktek Pendidikan dan Pendidikan Guru. Bandung: Kiblat Buku Utama.

As'ari, Ruli, and Nandang Hendriawan. 2016. "Kajian Nilai Kearifan Lokal Masyarakat Adat Kampung Naga dalam Pengelolaan Lingkungan Berbasis Mitigasi Bencana.” In Prosiding Seminar Nasional Geografi UMS 2016 Upaya 
CULTIVATING LOCAL WISDOM IN CHARACTER ...

Pengurangan Risiko Bencana Terkait Perubahan Iklim, 472-86. Surakarta: Muhammadiyah University Press. http://publikasiilmiah.ums.ac.id/handle/11617/8546.

Asriati, Nuraini. 2013. "Mengembangkan Karakter Peserta Didik Berbasis Kearifan Lokal Melalui Pembelajaran di Sekolah." Jurnal Pendidikan Sosiologi dan Humaniora 3 (2): 106-19.

Ayatrohaedi. 1986. Kepribadian Budaya Bangsa: (Local Genius). Jakarta: Dunia Pustaka Jaya.

Ernawi, Imam S. 2010. "Harmonisasi Kearifan Lokal Dalam Regulasi Penataan Ruang." In Harmonisasi Penataan Ruang Dan Budaya Untuk Mengoptimalkan Potensi Kota. Yogyakarta: Universitas Gadjah Mada.

Fajarini, Ulfah. 2014. "Peranan Kearifan Lokal dalam Pendidikan Karakter." Sosio-Didaktika: Social Science Education Journal 1 (2): 123-30. https://doi.org/10.15408/ sd.v1i2.1225.

Gunawan, Heri. 2012. Pendidikan Karakter: Konsep dan Implementasi. Bandung: Alfabeta.

Hamka. 2015. Falsafah Hidup: Memecahkan Rahasia Kehidupan Berdasarkan Tuntunan Al-Qur'an dan As-Sunnah. Mutiara Falsafah Buya Hamka. Jakarta: Republika.

Hasanah, Aan. 2012. "Pengembangan Pendidikan Karakter Berbasis Kearifan Lokal pada Masyarakat Minoritas: Studi atas Kearifan Lokal Masyarakat Adat Suku Baduy Banten.” Analisis : Jurnal Studi Keislaman 12 (1): 209-28. https://doi.org/10.42042/analisis.v12i1.637.

Keraf, A. Sonny. 2010. Etika Lingkungan Hidup. Jakarta: Penerbit Buku Kompas.

Kirschenbaum, Howard. 1995. 100 Ways To Enhance Values and Morality in Schools and Youth Settings. Allyn \& Bacon/Simon \& Schuster Educational Group. 
Koentjaraningrat. 2009. Sejarah Teori Antropologi. Depok: Penerbit Universitas Indonesia.

Larasati, Purwahyuningtyas. 2012. "Pelestarian Manuskrip Berdasarkan Kearifan Lokal Di KHP Widya Budaya Keraton Yogyakarta.” Skripsi, Depok: Universitas Indonesia.

Latif, Yudi. 2009. Menyemai Karakter Bangsa: Budaya Kebangkitan Berbasis Kesastraan. Jakarta: Penerbit Buku Kompas.

Lickona, Thomas. 2009. Educating for Character: How Our Schools Can Teach Respect and Responsibility. New York: Bantam Books.

Lubis, Zulkifli. 2008. "Potensi Budaya dan Kearifan Lokal Sebagai Modal Dasar Membangun Jati Diri Bangsa.” Jurnal Ilmu-Ilmu Sosial 9 (3): 339-46.

Magdalia, Alfian. 2013. "Potensi Kearifan Lokal Dalam Pembentukan Jati Diri Dan Karakter Bangsa.” In Proceedings of the 59th Ethnicity and Globalization, 424-35. Yogyakarta.

Maryani, Enok, and Ahmad Yani. 2016. "Kearifan Lokal Masyarakat Sunda dalam Memitigasi Bencana dan Aplikasinya Sebagai Sumber Pembelajaran IPS Berbasis Nilai.” Jurnal Penelitian Pendidikan 14 (2): 114-25.

Mulyadi, Agus. 2011. "SBY: Pendidikan Karakter Sangat Penting.” Kompas, May 2, 2011. https://nasional.kompas.com/ $\mathrm{read} / 2011 / 05 / 20 / 21473385 /$ SBY.Pendidikan.Karakter. Sangat.Penting.

Niode, Alim S. 2007. Gorontalo: Perubahan Nilai-nilai Budaya dan Pranata Sosial. Jakarta: Pustaka Indonesia Press.

Phillips, C. T. 2010. "Family as the School of Love.” In National Character Building: Opportunities and Challenges. Jakarta: Universitas Negeri Jakarta.

Pribadi, S. Bowo. 2012. "Lingkungan Keluarga Pengaruhi Pen- 
CULTIVATING LOCAL WISDOM IN CHARACTER ...

didikan Karakter Anak." Republika Online, February 15, 2012. https://republika.co.id/berita/gaya-hidup/parenting/12/02/15/lzfbhg-lingkungan-keluarga-pengaruhi-pendidikan-karakter-anak.

Priyatna, Muhammad. 2017. "Pendidikan Karakter Berbasis Kearifan Lokal." Edukasi Islami: Jurnal Pendidikan Islam 5 (10): 1311-36. https://doi.org/10.30868/ei.v5i10.6.

Rahimin Affandi Abd. Rahim, Ruzman Md Noor, Anuar Mohd Ramli, and Nor Hayati Md Dahlal. 2012. "Pemodenan dan Kesejahteraan Manusia dari Perspektif Orientalisme." Jebat: Malaysian Journal of History, Politics and Strategic Studies 39 (December): 1-23.

Rasyidin, Al, Parluhutan Siregar, and Khuzaimah Batubara. 2009. "Penyerapan Nilai-Nilai Budaya Lokal dalam Kehidupan Beragama di Medan: Studi Tentang Budaya Lokal di Medan" in Afif dan Bahri, Saeful." Harmonisasi Agama dan Budaya di Indonesia. Jakarta: Balitbang Kemenag.

Ruyadi, Yadi. 2010. "Model Pendidikan Karakter Berbasis Kearifan Budaya Lokal: Penelitian terhadap Masyarakat Adat Kampung Benda Kerep, Cirebon, Provinsi Jawa Barat untuk Pengembangan Pendidikan Karakter di Sekolah.” In Proceedings of The 4th International Conference on Teacher Education, 577-595. Bandung: Universitas Pendidikan Indonesia \& Universiti Pendidikan Sultan Idris.

Santoso, Budi. 1984. "Upacara Tradisional Kedudukan dan Fungsinya dalam Masyarakat." Majalah Analisis Kebudayaan, 1984.

Sumaryadi. 2012. “Kearifan Lokal Mesti Dilestarikan!” Yogyakarta: Universitas Negeri Yogyakarta

Suyanto. 2010. “Urgensi Pendidikan Karakter.” Babadan: Waskita Mandiri

Tilaar, Henry Alexis Rudolf. 2004. Paradigma Baru Pendidikan Nasional. Jakarta: Rineka Cipta. 
TESTIANI MAKMUR AND WENNY DASTINA

Warsidi, Edi. 2017. "Mewujudkan Penguatan Peran Keluarga dalam Pendidikan Anak." Tempo Media Group, March 1, 2017. https://indonesiana.tempo.co/ $\mathrm{read} / 108608 / 2017 / 03 / 01 /$ edi_warsidi/mewujudkan-penguatan-peran-keluarga-dalam-pendidikan-anak. 